\title{
Impact of education based on type 1 diabetes management model
}

\author{
Çağrı Çövener Özçelik • Ayșe Ferda Ocakçı
}

Received: 27 September 2012 / Accepted: 30 December 2014 / Published online: 18 February 2015

(C) Research Society for Study of Diabetes in India 2015

\begin{abstract}
The diabetes management is considered to be adversely affected when adolescent-specific education methods are not used. In this study, Type 1 Diabetes Management Model which ensures standardisation of the diabetes education and is based on the health promotion model and formed by applying health promotion model (HPM) according to the masterylearning theory was used. The study was performed to determine effectiveness of diabetes education based on "Type 1 Diabetes Management Model" on adolescents. In total, 36 adolescents at ages 13-17 with type 1 diabetes participated. A quasi-experimental study was conducted as a pretest-posttest design on a single group study, which included nine interactive type 1 diabetes education sessions over 8 days, with assessments at baseline and after 3 months. Diabetes management skills and self-management levels were measured with Diabetes Behaviour Rating Scale, General Self Efficacy Scale and diabetes knowledge measured with type 1 diabetes rating form and unit follow-up tests. After 3 months, diabetes management skills $(p=0.000)$ and self-management levels $(p=0.002)$ were improved, haemoglobin A1C levels were decreased $(p=0.035)$ and diabetes knowledge was increased $(p=0.000$ ). No improvement was observed in levels of taking the responsibility of skills $(p=0.958)$. Education programs based on Type 1 Diabetes Management Model may be suggested as an efficient model for adolescents with type 1 diabetes to improve their diabetes management skills, and also, diabetes nurses will be able to
\end{abstract}

Ç. Çövener Özçelik ( $($ )

Faculty of Health Sciences, Division of Nursing Department of Pediatric Nursing, Marmara University, Tibbiye Cad. No: 40 34668, Haydarpasa-Uskudar, Istanbul, Turkey

e-mail: ccovener@hotmail.com

Ç. Çövener Özçelik

e-mail: ccovener@gmail.com

A. F. Ocakç1

Koç University School of Nursing, Güzelbahçe sok. No:20 34365, Nişantaşı, Istanbul, Turkey form education programs they arrange within the framework of a specific standard.

Keywords Adolescent · Diabetes · Diabetes management . Health promotion model $\cdot$ Mastery-learning theory

\section{Introduction}

Individuals with type 1 diabetes (T1DM) constitute 5$10 \%$ of all diabetics in the world [1]. There are no recent studies determining incidence or and/or prevalence of T1DM in Turkey [2] but this ratio has been determined as $2.52 / 100,000$ per year according to an incidence study conducted on T1DM of ages $0-15$ in 1996 [3, 4]. Local studies, as in the whole world, show that frequency of T1DM has increased and the age of onset has shifted to younger ages [2].

It is necessary to follow-up T1DM cases in health centres with a paediatric endocrinologist, but in Turkey, this requirement could not be fulfilled even in major cities, as it turns out. There are diabetes nurses in limited number of paediatric endocrinology services; there are dieticians, psychologist and social services specialists in less of them. This situation hinders providing an integrated service to children and adolescents with diabetes [2]. Yet, planning the daily life for controlling the blood glucose level is an integral part of diabetes management. Many adolescents cannot adhere diabetes management due to various factors affected from individual causes [5]. Managing T1DM may frustrate the adolescent since it requires a strict adherence, consistency and responsibility $[5,6]$.

The goal of the adolescent is to become an adult and independent since the rules he is asked to obey doesn't 
accept immediately [7, 8]. Chronic diseases cause rage in adolescents since they restrain the independence [9], and these may lead to adverse effects on the diabetes management of the adolescent.

Diabetes education is acknowledged globally to ensure glycemic control, to reduce hospitalisations, to delay/prevent complications and to improve the metabolic control $[10,11]$. The diabetes education should be practised according to therapeutic patient education principles. The therapeutic patient education does not only enhance knowledge and skills regarding the disease but also ensures active involvement of the patients in his treatment and care. In chronic diseases such as diabetes in particular, it improves life quality of the individual [12].

The diabetes education is provided by qualified members of various disciplines such as physicians, nurses, dieticians, psychologists, social service specialists and paediatricians [13]. A diabetes nurse who is an indispensable member of the team practises the integral care process and considers the patient in physical and psychosocial aspects as a whole and also assists the patient and his family in learning the methods and skills that will facilitate them to convert knowledge into behaviour [14-16].

Diabetes educators use varied learning models/ theories for the diabetes education [17]. Growth characteristics of adolescents must be taken into account for the diabetes education [18]. The goal of the adolescent is to become an adult and independent and capable of directing his life as he wishes [8]. Thus, the family of the adolescent whose independence is important must not accompany the adolescent during the diabetes education [18].

Therapeutic education of the adolescent with diabetes must not only be about developing skills of an individual but also aim for behaviour change at the same time [12]. These approaches should be specific to the adolescent because diabetes management is thought to be adversely affected when adolescent-specific education methods are not used [5].

The metabolic control is affected from many factors like growth hormones, general health status, stress etc. during the adolescence in particular $[19,20]$. Therefore, optimal metabolic control would not be achieved despite the therapeutic education.

The diabetes education provided to adolescents with T1DM has not yet achieved a standard, and effectiveness of the education provided has not been proven. Theories and models establish a framework in order to systematise nursing practices, ensure that the individual is questioned, supervised and made to focus on his problems, develop systematic thinking and direct education and surveys $[21,22]$.
Aim of study

The study was performed to determine effectiveness of the T1DM education by using the "T1DM Management Model" on diabetes management of adolescents at ages 13-17.

The hypothesis of the study was,

The T1DM education provided by using the T1DM Management Model ensures diabetes management of adolescents at ages 13-17.

a. Diabetes management of adolescents with increased level of information on diabetes is improved.

b. Positive behaviour changes for diabetes occur in adolescents with improved diabetes management.

c. Metabolic controls of adolescents with improved diabetes management develop positively.

\section{Methods}

Participants

The study was conducted at the diabetes centre where the children and adolescent with T1DM follow-up were the most intense. Sampling criteria were identified as, haemoglobin A1C (A1C) level over $7.5 \%$ [20, 23], diabetes diagnosis is at least a year and regular follow-up. There were 392 adolescents registered in the diabetes centre. One hundred eighty adolescents meeting the sampling criteria were included in the study and phoned by the researcher and, 60 adolescents were contacted successfully. Thirty-six of 60 adolescents participated to the education program and the program was completed with these adolescents. Sample power analysis of the group of 36 was carried out at a significance level of 00.05 and it was calculated as 00.93 .

\section{Design}

A quasi-experimental study, pre-post test with single group design was used.

Instruments

Pre-education and post-education were measured using the following instruments:

Diabetes Behaviour Rating Scale (DBRS): The scale consists of 39 questions regarding diabetes management of adolescents aged 13-17. Frequency of behaviours related 
to diabetes management and level of responsibility assumed by adolescents are measured in each questions. The scale was developed by Cook et al. (2001) [19] and adapted to Turkish by Çövener (2005) [24]. Cronbach's alpha of the Turkish adaptation is 0.88 for the frequency and 0.93 for the responsibility [24]. There are seven subdimensions of the scale: insulin administration, meal planning, record keeping, safety, materials, illness and informing. As the score received from the 5-point likert type (for frequency, $1=$ never, $5=$ always; for responsibility, $\mathrm{E}(1)=\mathrm{It}$ 's all my parent's job, A(5)=It's all my job) scale is higher, the diabetes management is considered to be better.

General Self-Efficacy Scale (GSE): This scale was developed by Jeruselam and Schawazzer for individuals of ages 12 and over to measure self-efficacy of individuals and consists of 10 questions. The scale was adapted to Turkish. Cronbach alpha of the scale was found to be between 0.76 and 0.90 in studies conducted in 23 countries $[25,26]$. As the score increases in 4-point likert type scale ( $1=$ not at all true, $4=$ exactly true), the self-efficacy is considered to be higher.

Metabolic Control Measurement Form: It comprised information regarding $\mathrm{A} 1 \mathrm{C}$ results and presence of chronic complication and developed by the researcher considering similar studies.

Unit follow-up tests: These were tests applied to participants at the end of each unit constituting the education, developed to identify achievement of target behaviours in the relevant unit, consisting of multiple-choice questions related to cognitive field. The success in the unit followup test was considered as $80 \%$ of the group to score over $70 \%$ according to mastery-learning theory.

T1DM rating form: This is the test covering the nine units in the education program and comprised of 25 multiplechoice questions of cognitive, affective and behavioural fields. Total test score is evaluated over 100 points.

Data collection

\section{Assessment procedure}

Initially, demographical and clinical characteristics of patients were recorded. The instruments were applied on pre-education and post-education (8th day and 3 months later), and unit follow-up tests were applied at the end of each unit. In order to determine the status of behaviour change in participants, the instruments were re-applied through sending these to address of participants by post 3 months after the education program was completed. The education presentation used during the education was handed to the participants in booklet form after control tests were applied in order to prevent participants to be affected within the following 3-month period. These procedures were completed by the researcher.

\section{Interventions}

T1DM Management Model (Fig. 1) which aims the standardisation of the diabetes education is based on the health promotion model (HPM) and formed by applying HPM according to the mastery-learning theory (MLT). Continuing education until all individuals with diabetes achieve the same health promotion behaviour (effective diabetes management) was aimed with T1DM Management Model. HPM was developed by Nola Pender, and it describes the importance of cognitive processes healthpromoting behaviours of the individual [27, 28]. Although adequate steps necessary to promote health are provided in HPM, methods which should be used to take these steps are not described. Thus, MLT was utilised as the education method and integrated to HPM in the study (Fig. 2). MLT developed by Benjamin Bloom is an education philosophy based on the opinion that all new behaviours that can be learnt by any individual can be learnt by everyone when adequate learning conditions and enough time are provided [29-32].

Basic subjects that were absolutely required to be learnt for the diabetes management were identified, and nine chapters were formed: What is Diabetes?, T1DM and Healthy Nutrition, T1DM and Physical Activity-Exercise, Insulin, Self Management, Acute Complications of Diabetes, Chronic Complications of Diabetes, General Health Advices and Psychosocial Aspect of Diabetes contents of units were prepared in compliance with steps of T1DM Management Model. Purpose, objectives, duration, teaching methods and techniques of the course, tools and equipment to be used for teaching, content of the course, activities, evaluation and resources utilised were described in education plans established for each unit.

Education groups comprised three groups in total, each having 12 adolescents. Duration of each session varied between 60 and 120 min depending on the unit contents. Name tags were prepared to allow everyone to address each other with his name during interactive sessions. Since sessions were interactive, each group was made to sit on the floor to form a circle, everybody facing each other, and units were taught according to activities defined in the education plan. Little warming up games prepared by the researcher was played at the beginning of each session to ensure participants' warm-up. Units began with the drawing attention step. For this step, example cases were created by the researcher for likely situations that would be encountered and the participants were asked to find a solution for the problem. Answers of participants 


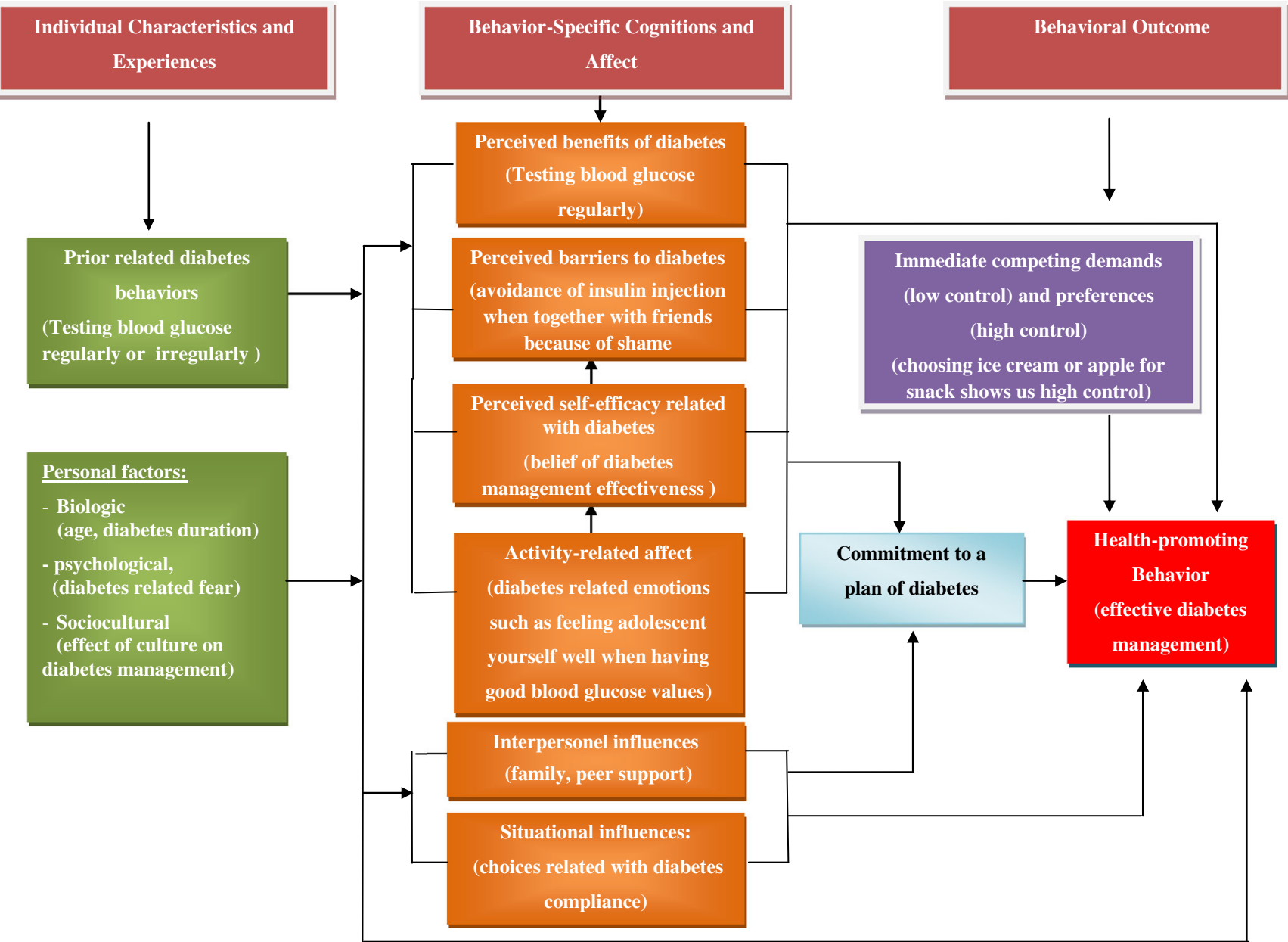

Fig. 1 Type 1 Diabetes (T1DM) Management Model

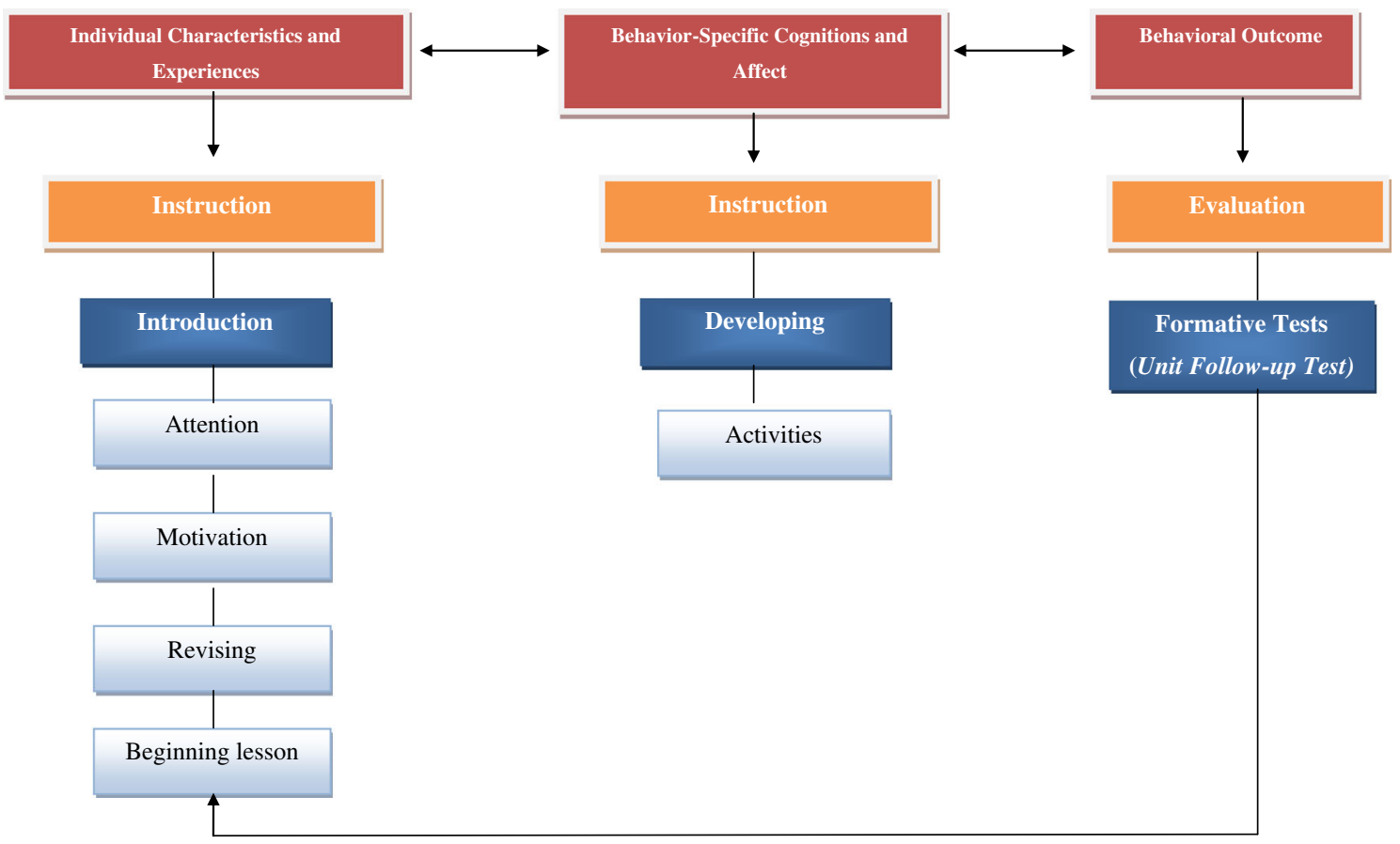

Fig. 2 Implementation of Pender's health promotion model according to mastery-learning theory 
Table 1 Demographic and clinical baseline variables of study participants

\begin{tabular}{|c|c|c|c|}
\hline Characteristic & & Number & Percentage \\
\hline \multirow[t]{2}{*}{ Sex } & Female & 19 & 52.8 \\
\hline & Male & 17 & 47.2 \\
\hline \multirow[t]{5}{*}{ Diabetes duration } & $1-3$ years & 6 & 16.7 \\
\hline & 4-6 years & 15 & 41.7 \\
\hline & $7-9$ years & 8 & 22.2 \\
\hline & $10-12$ years & 6 & 16.7 \\
\hline & $13-15$ years & 1 & 2.7 \\
\hline \multirow{6}{*}{$\begin{array}{l}\text { Frequency of } \\
\text { testing blood } \\
\text { glucose } \\
\text { (in a day) }\end{array}$} & Once & 1 & 2.8 \\
\hline & Twice & 3 & 8.3 \\
\hline & Thrice & 8 & 22.2 \\
\hline & 4 times & 18 & 50.0 \\
\hline & 5 times & 5 & 13.9 \\
\hline & 6 times & 1 & 2.8 \\
\hline \multirow{5}{*}{$\begin{array}{l}\text { Status of diabetes } \\
\text { education }\end{array}$} & Diabetes educator & & \\
\hline & Nurse & 21 & 58.3 \\
\hline & Physician & 2 & 5.6 \\
\hline & Diabetes camp & 2 & 5.6 \\
\hline & $\begin{array}{l}\text { Adolescents who had } \\
\text { diabetes } \\
\text { education before but } \\
\text { information learnt } \\
\text { was forgotten now }\end{array}$ & 11 & 30.6 \\
\hline TOTAL & & 36 & 100 \\
\hline
\end{tabular}

were listened, but no corrections were made on the answers. Following the drawing attention step, participants were motivated in respect to the unit and the importance of the unit was emphasised, unit contents were discussed and unit objectives were shown.

The unit is taught using interactive teaching methods and techniques in the activities step. The researcher generally directed participants with various questions as specified and ensured participants to find the answer or discuss the problem. Education cards prepared by the researcher, insulin pens, glucagon, glucometer and other treatment-related tools-equipment and video presentations were used in line with teaching methods and techniques during teaching the unit. The researcher provided feedback and made corrections at the end of each activity. The researcher gathered attention of the group between topics with interim summaries and transitions.

At the end of the unit, what was learnt in the unit were briefly summarised and the importance of the unit was emphasised once again by the researcher. In the closure section, the example case given in the drawing attention step was recalled, answers of participants were written on the board and necessary corrections were made.

At the end of each unit, the unit follow-up test of that unit was applied. The unit was repeated for participants who failed to achieve the success level and the unit follow-up test of that unit was re-applied at the end of it. When all the participants achieved the same level of success, they moved to the next unit and education was continued (all of these interventions have carried out referring to Fig. 2). The education program was completed in 8 days.

\section{Data analysis}

Statistical analysis was carried out using NCSS (Number Cruncher Statistical System) 2007 and PASS (Power Analysis and Sample Size) 2008 Statistical Software (Utah, USA). Number $(n)$ and percentage (\%) were used for socio-demographic data. Parametric data was analysed by paired sample $t$ test and repeated measures of variance analysis. Paired sample $t$ test was used for comparing scores pre-education and post-education. Repeated measures of variance analysis were performed for determining the difference between repeated measurements with Bonferroni correction. The results were evaluated within a $95 \%$ confidence interval and with a significance of $p<0.05$.

\section{Ethical considerations}

The study being a doctoral thesis research work (completed between January 2010-2012) was reviewed. Ethics approval was obtained from the ethics committee of the

Table 2 Comparison of DBRS and GSE mean scores in pre-education and post-education

\begin{tabular}{|c|c|c|c|c|c|}
\hline \multicolumn{2}{|l|}{ Scale } & \multirow{2}{*}{$\begin{array}{l}\text { Pre-education } \\
\text { Mean } \pm \text { SD (min-max) } \\
3.76 \pm 0.56(2.18-4.59)\end{array}$} & \multirow{2}{*}{$\begin{array}{l}\text { Post-education (3rd month) } \\
\text { Mean } \pm \text { SD (min-max) }\end{array}$} & \multirow{2}{*}{$\begin{array}{l}\text { Test value } \\
(t \text { test }) \\
5.79\end{array}$} & \multirow{2}{*}{$\begin{array}{l}p \text { values } \\
0.000^{* *}\end{array}$} \\
\hline DBRS & Frequency total score & & & & \\
\hline & Responsibility total score & $3.68 \pm 0.54(2.56-4.85)$ & $3.67 \pm 0.73(1.38-4.92)$ & 0.05 & 0.958 \\
\hline \multicolumn{2}{|c|}{ GSE total score } & $32.27 \pm 3.61$ & $34.50 \pm 3.90$ & 3.29 & $0.002 *$ \\
\hline
\end{tabular}

$t$ paired samples $t$ test, $S D$ standard deviation

${ }^{*} p<0.01 ; *{ }^{*} p<0.001$ 
Table 3 Comparison of mean scores of type 1 diabetes rating form in pre-education and post-education

\begin{tabular}{|c|c|c|c|c|c|}
\hline $\begin{array}{l}\text { Mean scores of type } 1 \text { diabetes } \\
\text { rating form }\end{array}$ & Min-max & Mean \pm SD & $\begin{array}{l}\text { The difference } \\
\text { between means }\end{array}$ & $\begin{array}{l}95 \% \text { confidence interval } \\
\text { of difference }\end{array}$ & $p$ values \\
\hline $\begin{array}{l}\text { Pre-education-post-education } \\
\text { (8th day) }\end{array}$ & $(12-56)$ to $(32-88)$ & $37 \pm 12.94-62.44 \pm 15.24$ & -25.44 & $(-31.10)$ to $(-19.79)$ & $0.000^{* *}$ \\
\hline $\begin{array}{l}\text { Pre-education-post-education } \\
\quad \text { (3rd month) }\end{array}$ & $(12-56)$ to $(28-84)$ & $37 \pm 12.94-56.11 \pm 15.07$ & -19.11 & $(-24.74)$ to $(-13.49)$ & $0.000 * *$ \\
\hline $\begin{array}{l}\text { Pre-education (8th day)-post- } \\
\text { education (3rd month) }\end{array}$ & $(32-88)$ to $(28-84)$ & $62.44 \pm 15.24-56.11 \pm 15.07$ & 6.33 & $1.39-11.28$ & $0.008^{*}$ \\
\hline
\end{tabular}

Test: repeated measures of variance analysis

$S D$ standard deviation

${ }^{*} p<0.0 ;{ }^{* *} p<0.001$

children's hospital. An informed and written consent was obtained from both parents and adolescents.

\section{Results}

Information on sociodemographical and clinical statuses of participants is given in Table 1 .

Total DBRS frequency mean score increased $12.2 \%$ $(p=0.000)$, and total GSE score increased $6.5 \%(p=$ 0.002 ) after the education compared to pre-education scores, and the differences between were found to be significant. No difference was detected in DBRS responsibility scores (Table 2).

In Table 3, it is shown that T1DM rating form mean scores on the 8 th day and in the 3rd month following the education were increased compared to pre-education mean scores and this increase was found to be significant $(p=0.000)$. This statistical difference shows that the levels of knowledge regarding diabetes on post-education were higher compared to pre-education levels. Despite the decrease between mean scores on the 8 th day and the $3 \mathrm{rd}$ month following the education (62.44/56.22 points), advanced significant difference was observed statistically $(p=0.008)$. Even though A1C level achieved the target for the age group of 13-17 (<7.5\%) [23] after the education, it decreased and this difference was found to be significant $(p=0.035)$ (Table 4$)$.

\section{Discussion and conclusions}

Results obtained from the study show that the diabetes education provided with T1DM Management Model was successful. Positive changes occurred in A1C levels in respect to diabetes-related behaviours of adolescents and their knowledge level increased.

It was proven by the studies that the diabetes education is critically important in the esffective management of diabetes [11, 33-41]. An adolescent with diabetes education is thought to have improved metabolic controls, and therefore, prevention of acute and chronic complications of diabetes becomes possible; thus, all adolescents with diabetes should be subjected the basic diabetes education. It is thought provoking that $30 \%$ of adolescents stated they did not remember the education they have received, according to the results obtained from the study. The impotency of the diabetes education given by a nurse in the study on $30 \%$ of the adolescents is thought to arise from lack of a standard, consistent and continuous education program. The positive results of a standard education provided with T1DM Management Model are seen in the study. Not every

Table 4 Comparison of $\mathrm{A} 1 \mathrm{C}$ values in pre and post-education

\begin{tabular}{llll}
\hline Metabolic control & $\begin{array}{l}\text { Pre-education } \\
\text { Mean } \pm \text { SD (min-max) }\end{array}$ & $\begin{array}{l}\text { Post-education (3rd month) } \\
\text { Mean } \pm \text { SD (min-max) }\end{array}$ & $\begin{array}{l}\text { Test value } \\
(\mathrm{t} \text { test })\end{array}$ \\
\hline A1C $(\%)$ & $9.67 \pm 1.59(7.60-14.00)$ & $9.29 \pm 1.49(6.50-13.00)$ & 2.19 \\
\hline
\end{tabular}

$t$ paired sample $t$ test; $S D$ standard deviation

$* p<0.05$ 
adolescent has the same learning skills and capacity. However, since there are specific rules and steps to a standard education, all adolescents with diabetes are able to have the opportunity to receive education until achieving the same level.

Steps of T1DM Management Model, established according to HPM, aim behaviour change to achieve the "effective diabetes management" which is a health promotion behaviour. In the study, behaviour change to occur in adolescents was measured by frequency of behaviours and the level responsibility assumed. It may be associated to the increased frequency of diabetes-related behaviours, the increase knowledge level of adolescents and understood importance of practices after the education. The adolescent's failure to achieve the expected level of responsibility is thought to be due to the characteristics of adolescence, the lack of adequate level of cognitive maturity and the complexity of the diabetes management. There are many studies supporting this situation regarding adolescents $[6,37,42,43]$.

Self-efficacy is very important for chronic disease management. As described in studies, the diabetes management becomes possible as the self-efficacy increases [11, 33, 44, 45]. After education, increase in self-efficacy scores shows that adolescents feel competent in managing the diabetes which is a chronic disease (Table 2). One of the steps of T1DM Management Model is associated with the perception of self-efficacy regarding diabetes. In the model, it was stated that the perception of self-efficacy plays an important role in initiating and continuing diabetes-related behaviours. Effective diabetes management was ensured, diabetes-related behaviours of adolescents were developed and metabolic controls were improved by developing the self-efficacy perception. These results show the success of the model.

As seen from the results, the result of T1DM rating form obtained post-education (8th day) is approximately twofold of the result of the same obtained pre-education. This result shows that incomplete, incorrect or absent information and knowledge was completed as a result of the diabetes education program. Despite the decrease in scores of T1DM rating form re-applied 3 months after the education program, the result was found to be higher than the pre-education scores. This decrease after 3 months is related to the recalling factor and is an anticipated result as stated in the literature [46]. Dashiff et al. has stated that it is possible to ensure an effective diabetes management by remedying lack of knowledge [47]. The significant difference between scores of T1DM rating forms applied on the 8th day and in 3rd month after the education shows that some of the knowledge and information learnt were actually forgotten. Thus, adolescents with diabetes should be continued to be monitored and education regarding diabetes management should be repeated on the basis of their needs, considering the recalling factor and arrival of new information and findings.
The education has been proven to be effective in the diabetes management and to improve the metabolic control, decreasing the $\mathrm{A} 1 \mathrm{C}$ value, by studies [11,33-41]. In the study, however, it is seen that the intended A1C level could not be achieved with a standardised education program. Even though the diabetes is effectively managed, the metabolic control is affected from many factors like growth hormones, general health status, stress etc. during the adolescence in particular $[19,20]$. The failure to achieve the intended A1C levels after the education is thought to be due to those factors.

There are some limitations to the study. No control group was used in the study because since the study was conducted within a specific period, the number of sample could not improve and also, follow-ups of adolescents regarding to manage their diabetes whether effectively or not after 6 months and 1 year were not performed.

In conclusion, this study shows that using T1DM Management Model and MLT as the teaching method has been beneficial and successful in achieving an effective diabetes management of adolescents. The hypothesis and sub-hypotheses of the study have been confirmed. However, it would be beneficial to conduct studies that will involve follow-ups of adolescents after 6 months and 1 year.

T1DM Management Model may be suggested to be used by diabetes nurses actively. Thus, diabetes nurses will be able to establish education programs they devised within a standard framework.

Acknowledgments The authors are grateful to all the participants and hospital staff for their insights.

Funding This research received no specific grant from any funding agency in the public, commercial or not-for-profit sectors.

Conflict of interest There is no conflict of interest for this research. All authors have information for submitting this article in the International Journal of Diabetes in Developing Countries.

\section{References}

1. American Diabetes Association (ADA). Diagnosis and classification of diabetes mellitus. Diabetes Care. 2012;35(1):S64-71.

2. Türkiye'de Diyabet Profili Çalıștay Raporu 2009. Çocukluk Çağında Diyabet Bakım ve Tedavisinin Geliştirilmesi. [Profile of diabetes in Turkey Workshop Report 2009. Improving of care and treatment of childhood diabetes]. Available at: www.diyabet2020.org. Accessed January 29, 2012.

3. Hatun S. Türk Diabet Yıllığı 2000-2001[Turkish Diabetes Annual 2000-2001]. İstanbul: Türk Diabet Cemiyeti Yayını, 2001: 65- 76.

4. Saka N. Diabetes mellitus. In: Günöz H, Öcal G, Yordam N, Kurtoğlu S, editors. Pediatrik Endokrinoloji [Pediatric endocrinology]. İstanbul: Pediatrik Endokrinoloji ve Oksoloji Derneği Yayınları; 2003. p. 415-23.

5. Amsberg S, Anderbro T, Wredling R, Lisspers J, Lins PE, Adamson $\mathrm{U}$, et al. A cognitive behavior therapy-based intervention among 
poorly controlled adult type 1 diabetes patients - a randomized controlled trial. Patient Educ Couns. 2009;77:72-80.

6. Greening L, Stoppelbein L, Konishi C, Jordan SS, Moll G. Child routines and youths' adherence to treatment for type 1 diabetes. $\mathrm{J}$ Pediatr Psychol. 2007;32:437-47.

7. Çuhadaroğlu F. Ergenlik Döneminde Psikolojik Gelișim Özellikleri [Characteristics of psychological development in adolescence]. Katk1 Pediatri. 2000;21:863-8.

8. Yavuzer H. Gençleri Anlamak. 2. baskı. İstanbul: Remzi Kitabevi; 2005.

9. Erdoğan A, Karaman MG. Kronik ve Ölümcül Hastalığı Olan Çocuk ve Ergenlerde Ruhsal Sorunların Tanınması ve Yönetilmesi. Anadolu Psikiyatri Dergisi. 2008;9:244-52.

10. Leite SAO, Zanim LM, Granzotto PCD, Heupa S, Lamounier RN. Educational program to type 1 diabetes mellitus patients: basic topics. Arq Bras Endrocrinol Metab. 2008;52:233-42.

11. Nansel TR, Iannotti RJ, Simons-Morton BG, Cox C, Plotnick LP, Clark LM, et al. Short-term and 1-year outcomes of a diabetes personal trainer intervention among youth with type 1 diabetes. Diabetes Care. 2007;30:2471-7.

12. Golay A, Lagger G, Chambouleyron M, Carrard I, Lasserre-Moutet A. Therapeutic education of diabetic patients. Diabetes Metab Res Rev. 2008;24:192-6.

13. Erdoğan S. Diyabet Eğitimi ve Danışmanlık. In: Erdoğan S, editor. Diyabet Hemşireliği Temel Bilgiler. İstanbul: Yüce Reklam/ Yayım/ Dağıtım AȘ; 2002. p. 163-82.

14. Fadıllığlu Ç. Diyabet Hemșiresi El Kitabı. Yılmaz C (ed). İzmir: Asya Tip Yayıncilık; 2002. pp. 74- 120.

15. Position Statement: Self-Management Education. Available at: www. idf.org. Accessed January 29, 2012.

16. Oktay S. Diyabet Bakımı:Sınırlar Ötesi Stratejiler. In: Erdoğan S, editor. Diyabet Hemşireliği Temel Bilgiler. İstanbul: Yüce Reklam/ Yayım/ Dağıtım AȘ; 2002. p. 1-10.

17. Bonnet C, Gagnayre R, D'Ivernois JF. Learning difficulties of diabetic patients: a survey of educators. Patient Educ Couns. 1998;35: 139-47.

18. Rankin SH, Stallings KD. Patient Education. $4^{\text {th }}$ ed. Philadelphia: Lippincott; 2001. pp. 99-107, 134-8.

19. Cook S, Aikens JE, Berry CA, McNabb WL. Development of the diabetes problem-solving measure for adolescents. Diabetes Educ. 2001;27:865-73.

20. Silverstein J, Klingensmith G, Copeland K, Plotnick L, Kaufman F, Laffel L, et al. Care of children and adolescents with type 1 diabetes. Diabetes Care. 2005;28:186-212.

21. Tokat Aluș M, Okumuș H. Bașarılı Emzirme İçin Kuram ve Modele Dayalı Hemşirelik Uygulamaları Nasıl Geliştirilir? [How develop nursing care based on theory and model for a successful breast feeding?]. Hemşirelikte Araştırma Geliştirme Dergisi (HEMAR-G). 2008;3:51-8.

22. Velioğlu P. Hemşirelikte Kavram ve Kuramlar. İstanbul: Alaş Ofset Matbaasi; 1999.

23. American Diabetes Association (ADA). Standards of medical care in diabetes - 2012. Diabetes Care. 2012;35(1):S11-63.

24. Çövener Ç. Tip 1 Diyabetli Adolesanlarda Sorun Çözme Becerisi. Marmara University Health Sciences Institute. Master Thesis. İstanbul, 2005 (Advisor: Prof. Dr. H Pek).

25. General Self Efficacy Scale. Available at: http://userpage.fu-berlin. de/health/selfscal.htm, Accesed February 20, 2011.

26. Terzi Ș. Üniversite öğrencilerinde kendini toparlama gücünün içsel koruyucu faktörlerle ilișkisi. Hacettepe Üniversitesi Eğitim Fakültesi Dergisi (HU J Educ). 2008;35:297-306.
27. Akça AF. Mesleki Temel Kavramlar. In: Akça Ay F, editor. Temel Hemşirelik Kavramları, İlkeler, Uygulamalar. İstanbul: Medikal Yayıncilik; 2007. p. 39-47.

28. Sakraida TJ. Nola Pender: health promotion model. In: Alligood MR, Tomey AM, editors. Nursing theorists and their work. 7th ed. Maryland: Mosby; 2010. p. 434-54.

29. Bloom BS, Carroll JB. Mastery learning. In: Block JH, editor. Mastery learning theory and practice. New York: Rinehart and Winston Inc; 1971. p. 47-63.

30. Bloom BS. İnsan Nitelikleri ve Okulda Öğrenme (Human characteristics and school learning). Translation: Özçelik DA. Istanbul Milli Eğitim Basımevi: Istanbul; 1998.

31. Erden M, Akman Y. Gelișim ve Öğrenme. Genișletilmiş 9. bask1. Ankara: Arkadaş Yayınevi; 2001. p. 242-7.

32. Demirel O. Ögretme Sanatı. Geliştirilmiş 14. baskı. Ankara: Pegem Akademi; 2009. p. 132-6.

33. Rubin RR, Peyrot M, Saudek CD. Effect of diabetes education on self-care, metabolic control, and emotional well-being. Diabetes Care. 1989;12:673-9.

34. Delamater AM, Bubb J, Davis SG, Smith JA, Schmidt L, White NH, et al. Randomized prospective study of self-management training with newly diagnosed diabetic children. Diabetes Care. 1990;13: 492-8.

35. Couper JJ, Taylor J, Fotherıngham MJ, Sawyer M. Failure to maintain the benefits of home-based intervention in adolescents with poorly controlled type 1 diabetes. Diabetes Care. 1999;22:1933-7.

36. Sidorov J, Gabbay R, Harris R, Shull RD, Girolami S, Tomcavage J, et al. Disease management for diabetes mellitus: impact on hemoglobin A1C. Am J Manage Care. 2000;6:1217-26.

37. Cook S, Herold K, Edidin DV, Briars R. Increasing problem solving in adolescents with type 1 diabetes : the choices diabetes program. Diabetes Educ. 2002;28:115-24.

38. Gage H, Hampson S, Skinner TC, Hart J, Storey L, Foxcroft D, et al. Educational and psychosocial programmes for adolescents with diabetes: approaches, outcomes and cost-effectiveness. Patient Educ Couns. 2004;53:333-46.

39. Warsi A, Wang PS, LaValley MP, Avorn J, Solomon DH. Selfmanagement education programs in chronic disease: a systematic review and methodological critique of the literature. Arch Intern Med. 2004;164:1641-9.

40. Liebman J, Heffernan D, Sarvela P. Establishing diabetes selfmanagement in a community health center serving low-income Latinos. Diabetes Educ. 2007;33(6):132S-8S.

41. Cochran J, Conn VS. Meta-analysis of quality of life outcomes following diabetes self-management training. Diabetes Educ. 2008;34(5):815-23.

42. Ingersoll GM, Orr DP, Herrold AJ, Golden MP. Cognitive maturity and self-management among adolescents with insulin-dependent diabetes mellitus. J Pediatr. 1986;108:620-3.

43. Harris MA, Wysocki T, Sadler M, Wilkinson K, Harvey LM, Buckloh LM, et al. Validation of a structured interview for the assessment of diabetes self-management. Diabetes Care. 2000;23: $1301-4$.

44. Wu SFV, Lee MC, Liang SY, Lu YY, Wang TJ, Tung HH. Effectiveness of a self-efficacy program for persons with diabetes: a randomized controlled trial. Nurs Health Sci. 2011;13:335-43.

45. Iannotti RJ, Schneider S, Nansel TR, Haynie DL, Plotnick LP, Clark LM, et al. Self-efficacy, outcome expectations, and diabetes self management in adolescents with type 1 diabetes. J Dev Behav Pediatr. 2006;27:98-105.

46. Başar H. Sınıf Yönetimi. Milli Eğitim Basımevi: İstanbul; 1999.

47. Dashiff CJ, McCaleb A, Cull V. Self-care of young adolescents with type 1 diabetes. J Pediatr Nurs. 2006;21:222-32. 